\title{
PENGARUH KARAKTERISTIK ORANGTUA DAN SEKOLAH TERHADAP TINGKAT KEPUASAN PELAYANAN PENDIDIKAN DASAR
}

\author{
The Effect of Parents' and School Characteristics on Satisfaction Level of Basic \\ Education Services
}

\author{
ATIKA RAHMA ${ }^{1^{*}}$, HARTOYO ${ }^{2}$ \\ ${ }^{1}$ Departemen IImu Keluarga dan Konsumen, Fakultas Ekologi Manusia, Institut Pertanian Bogor, \\ Kampus Dramaga, Bogor 16680 \\ ${ }^{2}$ Staf Pengajar Departemen Ilmu Keluarga dan Konsumen, Fakultas Ekologi Manusia, Institut \\ Pertanian Bogor, Jalan Lingkar Kampus IPB Dramaga, Bogor 16680
}

\begin{abstract}
School is an important role in human capital development. Therefore, school should perform good education services. The objective of this study is to analyze some factors that influence parents' satisfaction level of basic education services. This study used a cross sectional design and carried out at four Sub-Districts of Indramayu District. Samples of this study consist of 126 of elementary and secondary school students. The results of observation showed that the condition of school facility was in a medium category. Parents in elementary and secondary school in and out of town felt satisfy toward basic education services, but parents in secondary school and town were more satisfied than in elementary school and out of town. Based on the Importance and Performance Analysis (IPA), the attributes of education services that must be improved, were student toilets, chairs and desks, library, BOS fund and BOS fund for books. The attribute that must be repaired in particular at elementary school was information to parents about performance of their children, whereas attribute of blue uniform cost must be repaired by secondary school. While special for secondary school in out of town that must be repaired was maintenance of school building. Logistic regression analysis showed some factors that influence the parent satisfaction level (CSI indicator) were family size, fathers' age, and school facilities. While, family size, length of father education, valuation father toward education services, and CSI score influence parent satisfaction level (direct reported satisfaction).
\end{abstract}

\section{Key words: Consumer Satisfaction Index (CSI), Importance and Performance Analysis (IPA), satisfaction level, school facility}

\section{PENDAHULUAN}

Pendidikan memegang peran yang sangat penting dalam proses peningkatan kualitas sumberdaya manusia (SDM). Dalam Undang-undang Sistem Pendidikan Nasional Nomor 20 Tahun 2003 dinyatakan bahwa pendidikan nasional berfungsi mengembangkan kemampuan dan membentuk watak serta peradaban bangsa yang bermartabat dalam rangka mencerdaskan kehidupan bangsa, bertujuan untuk berkembangnya potensi peserta didik agar menjadi manusia yang beriman dan bertakwa kepada Tuhan Yang Maha Esa, berakhlak mulia, sehat, berilmu, cakap, kreatif, mandiri, dan menjadi warga negara yang demokratis serta bertanggung jawab (Pasal 3). Keluarga sebagai unit terkecil dari masyarakat merupakan institusi yang sangat strategis dalam menciptakan SDM yang berkualitas. Peraturan Pemerintah Republik Indonesia Nomor 21 Tahun 1994 telah merumuskan delapan fungsi keluarga sebagai jembatan menuju terbentuknya sumberdaya manusia yang handal. Salah satu fungsi yang berkaitan dengan pembentukan sumberdaya manusia adalah fungsi pendidikan dan sosialisasi. Fungsi pendidikan dapat dilakukan melalui sekolah dengan memberikan pengetahuan dan keterampilan. Komitmen tersebut tentunya perlu didukung oleh pihak pemerintah (sebagai penyedia pelayanan pendidikan) dengan memberikan mutu yang 
terbaik kepada siswa dan orangtua sebagai pengguna jasa pendidikan.

Pemerintah pusat dan daerah wajib memberikan pelayanan dan kemudahan, serta menjamin terselenggaranya pendidikan bermutu bagi warga negara tanpa diskriminasi (Pasal 11 Ayat 1). Salah satu upaya pemerintah adalah dengan mengalokasikan dana pendidikan tahun 2009 sebesar 20\% yang digunakan untuk pembiayaan dana BOS dan BOS buku dengan tujuan meringankan beban orangtua terutama keluarga dengan tingkat ekomoni lemah, sehingga tidak ada hambatan lagi bagi mereka untuk mengakses pendidikan.

Pelayanan pendidikan dasar yang diberikan pemerintah tidak hanya berkaitan dengan biaya, tetapi juga kualitas yang melekat pada sekolah, seperti fasilitas fisik dan nonfisik. Dalam hal ini, peran pemerintah sebagai penyedia pelayanan diwakili oleh sekolah, karena sekolah merupakan satuan unit pendidikan yang berinteraksi secara langsung dengan orangtua dan siswa. Sesuai dengan Tiga Pilar Pendidikan yaitu pemerataan dan perluasan akses; peningkatan mutu, relevansi, dan daya saing; serta penguatan tata kelola, akuntabilitas, dan citra publik; maka sekolah harus menjaga dan meningkatkan mutu pelayanan pendidikan yang diberikannya, karena apabila mutu pelayanan yang diterima oleh orangtua lebih baik atau sama dengan yang dibayangkan, mereka cenderung akan loyal terhadap sekolah tersebut.

Loyalitas orangtua merupakan manifestasi dan kelanjutan dari kepuasan orangtua setelah menggunakan jasa pelayanan yang diberikan oleh sekolah. Sumarwan (2003) menjelaskan proses pembentukkan kepuasan melalui the expectancy disconfirmation model, yaitu kepuasan yang terbentuk setelah membandingkan harapan mengenai bagaimana produk tersebut seharusnya berfungsi (performance expectation) dengan kinerja produk sesungguhnya (actual performance). Sementara itu, attribution theory (Mowen \& Minor 1998) menyatakan bahwa kepuasan pelanggan terbentuk karena kualitas atribut produk. Atribut produk tersebut terdiri atas atribut internal dan atribut eksternal. Atribut internal berkaitan dengan baik/buruknya kualitas produk. Sementara itu yang dimaksud dengan atribut eksternal adalah keramahan pegawai terhadap pelanggan, pelayanan purnajual, dan adanya potongan harga. $\begin{array}{ccc}\text { Mowen } & \text { dan Minor } & \text { (1998) juga } \\ \text { memaparkan } & \text { proses } & \text { pembentukkan }\end{array}$ kepuasan melalui equition theory, yaitu menganalisis kepuasan berdasarkan pertukaran input yang dikeluarkan pelanggan dan outcomes yang didapatkan pelanggan. Input pelanggan terdiri dari pencarian informasi, usaha yang dilakukan, uang, dan waktu yang dikorbankan untuk mendapatkan produk. Sementara itu, outcomes pelanggan terdiri dari manfaat dan kerugian yang didapat setelah proses pertukaran berlangsung.

Evaluasi pelayanan pendidikan dasar dilakukan dengan cara mengetahui tingkat kepuasan orangtua dapat diketahui melalui membandingkan kualitas fasilitas yang disediakan sekolah dengan yang diharapkan orangtua (the expectancy disconfirmation model), menilai kualitas fasilitas fisik dan nonfisik (attribution theory) dan membandingkan biaya yang dikeluarkan dan pelayanan yang didapat oleh orangtua (equition theory). Hasilnya dapat dijadikan sebagai bahan acuan untuk meningkatkan pelayanan pendidikan dan menikatkan partisipasi masyarakat untuk lebih peduli dan berperan serta dalam menciptakan sumberdaya berkualitas.

Berdasarkan latar belakang tersebut, maka tujuan penelitian ini adalah: (1) menganalisis tingkat kepuasan orangtua terhadap pelayanan pendidikan dasar dengan pertanyaan langsung (direct reported satisfaction) dan menggunakan CSI (Consumer Satisfaction Index); (2) menganalisis kinerja atribut pelayanan pendidikan dasar dengan menggunakan IPA (Importance Performance Analysis); dan (3) menganalisis faktor-faktor yang mempengaruhi kepuasan orangtua terhadap pelayanan pendidikan dasar.

\section{METODE}

Desain, Lokasi, dan Waktu

Desain yang digunakan adalah cross sectional study. Penelitian dilakukan di empat kecamatan Kabupaten Indramayu yang dipilih secara purposive, yaitu Kecamatan Indramayu, Kecamatan Sindang, Kecamatan Karangampel, dan Kecamatan Kandanghaur. Penelitian dilaksanakan Februari hingga Mei 2009.

\section{Contoh dan Cara Penarikan Contoh}

Contoh adalah siswa Kelas 6 SD dan Kelas 3 SMP. Sementara itu, yang menjadi 
responden adalah orangtua atau wali siswa. Berdasarkan total contoh sebanyak 400, dipilih dengan kriteria orangtua lengkap (ayah dan ibu) sehingga contoh yang didapatkan sebanyak 126 siswa. Untuk kepentingan analisis, contoh dikelompokkan berdasarkan tingkat pendidikan contoh (SD dan SMP) dan lokasi tempat tinggal (kota dan luar kota).

\section{Jenis dan Pengumpulan Data}

Jenis data yang dikumpulkan meliputi data sekunder yang terdiri dari: (1) karakteristik keluarga responden; (2) persepsi orangtua terhadap pendidikan dasar; (3) tingkat kepuasan orangtua (direct reported satisfaction); (4) tingkat kepentingan orangtua terhadap pelayanan pendidikan dasar; (5) tingkat kinerja pelayan pendidikan dasar; serta (6) ketersediaan dan kondisi fasilitas fisik di sekolah contoh. Data yang dipergunakan adalah data sekunder dari penelitian Puspitawati et al. (2009) "Survey Kepuasan Orangtua terhadap Pelayanan Pendidikan Dasar yang Disediakan oleh Sistem Desentralisasi Sekolah".

\section{Pengolahan dan Analisis Data}

Data yang telah diperoleh kemudian dianalisis dengan menggunakan Microsoft Excel dan SPSS for windows. Analisis yang dilakukan meliputi: (1) tabel analisis deskriptif dalam menganalisis hubungan antara dua variabel; (2) analisis tingkat kepuasan orangtua (CSI); (3) analisis deskriptif dengan mempergunakan diagram (4 kuadran) dalam menganalisis kepuasan orangtua; (4) korelasi Pearson; dan (5) analisis regresi logistik.

\section{HASIL DAN PEMBAHASAN}

\section{Karakteristik Contoh}

Tingkat pendidikan contoh yang tinggal di kota lebih banyak SMP $(75,4 \%)$, sedangkan contoh diluar kota mayoritas berasal dari SD $(66,2 \%)$. Baik di kota $(59 \%)$ maupun di luar kota $(63,1 \%)$, contoh lebih banyak berjenis kelamin perempuan dibandingkan dengan laki-laki. Berdasarkan kelompok umur, proporsi terbesar berada pada kelompok umur $\leq 12$ tahun $(42,9 \%)$ untuk luar kota dan $\geq 15$ tahun $(50,8 \%)$ untuk kota. Separuh contoh di kota $(55,7 \%)$ dan luar kota $(55,4 \%)$ merupakan anak urutan ke satu dan dua.

\section{Karakteristik Keluarga Contoh}

Berdasarkan lokasi tempat tinggal, proporsi responden tinggal di luar kota adalah $51,6 \%$, sisanya $48,8 \%$ di kota. Umur responden ayah di kota $(70,5 \%)$ dan di luar kota $(66,2 \%)$ termasuk kategori dewasa madya (Hurlock 1980), sedangkan 53,7\% responden ibu di luar kota dan 47,5\% responden ibu di kota merupakan kelompok umur dewasa awal. Tingkat pendidikan responden ayah di kota adalah tidak tamat SD (29,5\%), sedangkan di luar kota adalah tamat SMA $(27,7 \%)$. Sekitar seperlima $(21,3 \%)$ responden ibu di kota dan seperempat $(24,6 \%)$ responden ibu di luar kota tingkat pendidikannya adalah tidak tamat SD. Jenis pekerjaan mayoritas responden ayah di kota $(24,6 \%)$ dan di luar kota $(35,4 \%)$ adalah sebagai buruh, sedangkan mayoritas responden ibu baik di kota dan di luar kota tidak memiliki pekerjaan. Secara umum, hampir separuh responden di kota $(44,3 \%)$ dan di luar kota $(43,1 \%)$ termasuk ke dalam kelompok keluarga sedang (5-7 orang per keluarga). Pendapatan per kapita responden di kota $(63,9 \%)$ dan di luar kota $(78,5 \%)$ termasuk ke dalam kategori di bawah garis kemiskinan.

\section{Persepsi Orangtua Terhadap Pendidikan Dasar}

Secara umum orangtua di kota dan di luar kota memiliki persepsi kategori sedang $(50,8 \%)$ dan baik $(49,2 \%)$, artinya orangtua menyadari bahwa pendidikan dasar merupakan hak setiap anak. Selain itu, pendidikan dasar juga merupakan landasan untuk melanjutkan pendidikan ke jenjang yang lebih tinggi maupun sebagai modal untuk membentuk kemandirian. Namun, orangtua masih memiliki kesadaran rendah dalam hal mengeluarkan biaya pendidikan, karena tiga perempat orangtua $(75,4 \%)$ setuju bahwa biaya pendidikan sepenuhnya menjadi tanggung jawab pemerintah.

\section{Kondisi Fasilitas Sekolah}

Hasil observasi menunjukkan bahwa kondisi fasilitas fisik termasuk kategori sedang $(52,6 \%)$, artinya fasilitas tersebut seperti gedung sekolah, kursi, bangku, kebersihan lingkungan, dan media pembelajaran masih dalam kondisi layak pakai walaupun ada beberapa fasilitas yang masih harus diperbaiki. Kondisi fasilitas fisik yang buruk lebih banyak terdapat pada sekolah di luar kota $(28,6 \%)$ dan di tingkat SMP $(26,1 \%)$, sedangkan kondisi yang baik 
lebih banyak di sekolah kota $(35,3 \%)$ pada tingkat juga di SMP $(34,8 \%)$. Kategori buruk tersebut ditunjukkan dengan adanya kerusakan pada fasilitas gedung, fasilitas toilet, dan perpustakaan.

Proses pembelajaran dan pengajaran sekolah termasuk pada kategori sedang $(60,5 \%)$. Hal ini ditunjukkan dengan kegiatan sekolah yang melakukan home visit jika ada siswa bermasalah, pemajangan hasil karya siswa, dan pengaturan ruangan yang tidak bersifat tradisional. Sekolah di kota lebih banyak berada pada kondisi buruk $(23,5 \%)$ dibandingkan sekolah di luar kota $(14,3 \%)$. Kondisi buruk tersebut lebih banyak dimiliki pada tingkat SD dibandingkan SMP, terutama dalam hal pengaturan ruangan yang tidak bersifat tradisional dan home visit pada siswa bermasalah.

Kondisi manajemen sekolah secara umum termasuk kategori sedang $(84,2 \%)$, artinya sekolah sudah cukup baik dalam hal melakukan perencanaan sekolah tahunan, manajemen data guru, dan siswa serta pemajangan atribut sekolah (profil sekolah, visi, dan misi sekolah). Sekolah di kota memiliki persentase kategori buruk lebih besar $(11,8 \%)$ dibandingkan dengan sekolah di luar kota $(9,5 \%)$, yaitu dalam hal adanya wakil kepala sekolah dan data guru serta tenaga administrasi. Sementara itu, untuk kategori baik, persentase sekolah di kota juga lebih besar $(5,9 \%)$ dibandingkan dengan di luar kota $(4,8 \%)$, yaitu atribut pemasangan visi dan misi di tempat strategis, data komite sekolah terpilah jenis kelamin, data pelatihan guru terpilah jenis kelamin, dan struktur organisasi dipajang di tempat yang strategis.

Tata tertib sekolah contoh berada pada kategori baik dan tidak ada satu pun yang termasuk kategori buruk, artinya bahwa sekolah telah memajang tata tertib sekolah di tempat yang strategis, minimnya hukuman fisik dan nuansa kekerasan (pada saat dilakukan pengamatan). Kategori baik persentase untuk sekolah di kota lebih kecil $(70,6 \%)$ dibandingkan sekolah di luar kota $(71,4 \%)$, karena masih ada sekolah di kota yang menerapkan hukuman fisik.

Hasil pengamatan menunjukkan bahwa kondisi fasilitas sekolah secara umum termasuk pada kategori sedang $(62,7 \%)$. Fasilitas tersebut berkait dengan fasilitas fisik, proses pembelajaran, manajemen sekolah, dan tata tertib sekolah. Fasilitas sekolah di kota $(29,5 \%)$ lebih baik dibandingkan sekolah di luar kota $(12,3 \%)$. Sementara itu fasilitas di SMP $(33,8 \%)$ persentase kategori baik lebih besar dibandingkan di SD $(5,2 \%)$. Sekolah SMP di kota memiliki fasilitas yang lebih baik dibandingkan sekolah lainnya. Hal ini disebabkan karena sekolah tersebut merupakan sekolah unggulan tidak hanya di kecamatan, tetapi juga di kabupaten. Sekolah unggulan pada umumnya mendapatkan perhatian dan fasilitas lebih dari pemerintah dibandingkan sekolah lainnya dalam hal penyediaan sarana dan prasarana.

\section{Kepuasan yang Dilaporkan Langsung (Direct Reported Satisfaction)}

Direct reported satisfaction yaitu kepuasan yang diukur dengan menanyakan secara langsung tingkat kepuasan kepada orangtua berkaitan dengan sembilan atribut pelayanan pendidikan dasar. Secara umum orangtua merasa cukup puas dan puas terhadap pelayanan pendidikan yang diberikan sekolah. Orangtua merasa puas terhadap pelayanan pendidikan di sekolah berkaitan dengan atribut seperti proses pembelajaran (SD, SMP, kota, luar kota), kualitas pengajaran (SD, SMP, kota, luar kota), hasil dari proses pembelajaran (SD, SMP, kota, luar kota), sekolah dapat menjaga disiplin dan kemanan lingkungannya (SMP, kota, luar kota), sekolah dapat mendorong keterlibatan orangtua (SMP, kota, luar kota), dan kualitas fisik sekolah (SMP, kota). Sementara itu, kategori cukup puas berkaitan dengan atribut kondisi sekolah yang nyaman (SD, SMP, kota, luar kota), sekolah dapat menjaga disiplin dan keamanan lingkungannya (SD), sekolah dapat mendorong keterlibatan orangtua (SD), kualitas fasilitas fisik (SD, luar kota), kesiapan alih tahun pelajaran (SD, SMP, kota, luar kota) dan ketersediaan biaya pendidikan (SD, SMP, kota, luar kota).

Tingkat kepuasan ayah dan ibu berada pada kategori puas, namun secara detai ditemukan bahwa responden ibu lebih puas $(91,3 \%)$ dibandingkan dengan ayah $(88,1 \%)$. Hal ini diduga karena metode pengukuran kepuasan bersifat subjektif sangat dipengaruhi oleh emosi seseorang. Ibu dalam menilai kepuasan subjektif, dirasakan sangat dipengaruhi oleh perasaannya (Troelstrup 1957).

Tingkat kepuasan orangtua berdasarkan tingkat pendidikan contoh menunjukkan bahwa ayah $(84,5 \%)$ dan ibu $(86,2 \%)$ di SD termasuk kategori puas. Hasil yang sama juga ditunjukkan oleh responden ayah $(91,2 \%)$ dan ibu $(95,6 \%)$ di tingkat SMP. 
Namun, responden ayah dan ibu di SMP lebih merasa puas dibandingkan dengan responden ayah dan ibu di SD.

Berdasarkan lokasi sekolah, tingkat kepuasan responden ayah $(93,4 \%)$ dan ibu $(91,8 \%)$ di kota berada pada kategori puas. Sementara itu, sekolah di luar kota baik responden ayah $(83,1 \%)$ dan ibu $(90,8 \%)$ juga berada pada kategori puas. Responden ayah dan ibu yang merasa tidak puas lebih banyak berada pada responden di luar kota dibandingkan di kota.

Hasil crosstab terhadap kepuasan ayah dan ibu menunjukkan bahwa terdapat $82,5 \%$ responden ayah dan ibu yang tingkat kepuasaannya sama-sama termasuk ke dalam kategori puas dan 3,2\% yang samasama termasuk kategori tidak puas. Sementara itu terdapat $8,7 \%$ responden ibu yang kepuasannya lebih tinggi dibandingkan ayah dan $5,6 \%$ ayah yang kepuasannya lebih tinggi dibandingkan ibu.

\section{Derived Satisfaction}

Derived satisfaction mengukur melalui besar harapan orangtua terhadap atribut pelayanan pendidikan dasar dan besarnya kinerja yang mereka rasakan. Penghitungannya dilakukan dengan menggunakan rumus CSI (Consumer Satisfaction Index). Penilaian yang telah dilakukan terhadap 40 atribut pelayanan pendidikan dasar oleh orangtua menghasilkan skor 0,709. Hal ini berarti orangtua merasa puas terhadap pelayanan pendidikan dasar yang disediakan sekolah. Bila dilihat per individu, hampir tiga perempat responden ayah $(71,4 \%)$ dan ibu $(73 \%)$ merasa puas.

Secara umum, responden ayah dan ibu baik di SD dan SMP termasuk ke dalam kategori puas. Hasil penghitungan tingkat kepuasan ayah dan ibu di SD menunjukkan nilai yang sama, yaitu ibu dan ayah yang merasa cukup puas sebanyak $25,9 \%$ dan puas $74,1 \%$.

Berdasarkan lokasi sekolah, responden ayah dan ibu di kota maupun di luar kota berada pada kategori puas. Resonden ayah $(73,8 \%)$ dan ibu $(75,4 \%)$ di kota lebih banyak puas dibandingkan dengan responden ayah $(69,2 \%)$ dan ibu $(70,8 \%)$ di luar kota.

Sementara itu, crosstab antara indeks kepuasan ayah dan ibu secara umum menunjukkan kekonsistenan diantara keduanya. Ayah dan ibu yang sama-sama puas terhadap pelayanan pendidikan dasar adalah sebesar $(61,1 \%)$. Sementara itu, ayah dan ibu yang sama-sama termasuk ke dalam kategori cukup puas adalah sebanyak $15,1 \%$. Persentase ini lebih baik jika dibandingkan dengan hasil crosstab pada kepuasan yang dilaporkan langsung.

\section{Analisis Tingkat Kepentingan dan Kinerja (Importance and Performance Analysis)}

Atribut pelayanan di SD dan SMP yang perlu diperbaiki (Kuadran A) adalah ketersediaan toilet siswa, kondisi meja serta bangku sekolah, keberadaan dan kondisi perpustakaan, kontribusi dana BOS dan BOS buku terhadap total biaya pendidikan sehingga dapat mengurangi beban orangtua. $\mathrm{Di}$ sekolah dasar, kinerja berkaitan dengan pemberian informasi mengenai perkembangan anak kepada orangtua juga perlu diperbaiki. Sementara itu, di tingkat SMP, orangtua berharap sekolah dapat meningkatkan kinerjanya dalam memelihara bangunan dan halaman sekolah.

Atribut pelayanan di SD dan SMP yang termasuk dalam Kuadran D (tingkat kepentingan dan kinerjanya dinilai rendah) adalah pihak sekolah dapat memotivasi partisipasi masyarakat dalam menjaga lingkungan sekolah, ketersediaan peralatan olahraga, tersedianya lapangan olahraga, besarnya biaya yang ditanggung oleh orangtua, orangtua mengeluarkan biaya transport, orangtua mengeluarkan biaya buku-buku, orangtua mengeluarkan biaya Lembar Kerja Siswa (LKS), orangtua mengeluarkan biaya peralatan sekolah, orangtua mengeluarkan biaya seragam dan uang saku. Atribut Kuadran D mayoritas berkaitan dengan permasalahan biaya pendidikan. Orangtua memiliki persepsi bahwa biaya pendidikan seluruhnya merupakan tanggung jawab pemerintah. Hal ini mengindikasikan bahwa kesadaran orangtua akan tanggung jawabnya untuk mengeluarkan biaya pendidikan pribadi (peralatan sekolah, uang saku) masih kurang.

Sementara itu, sekolah di kota dan di luar kota menurut orangtua yang perlu diperbaiki (Kuadran A) adalah ketersediaan toilet siswa, kondisi meja serta bangku sekolah, keberadaan dan kondisi perpustakaan, kontribusi dana BOS, dan BOS buku terhadap total biaya pendidikan sehingga dapat mengurangi beban orangtua.

Atribut yang terdapat di Kuadran C hanya satu dan itu berada pada sekolah di luar kota. Atribut yang dimaksud adalah guru tidak memukul siswa. Atribut pelayanan pihak sekolah dapat memotivasi partisipasi masyarakat dalam menjaga lingkungan 
sekolah, ketersediaan peralatan olahraga, tersedianya lapangan olahraga, besarnya biaya yang ditanggung oleh orangtua, orangtua mengeluarkan biaya transport, orangtua mengeluarkan biaya buku-buku, Lembar Kerja Siswa (LKS), orangtua mengeluarkan biaya peralatan sekolah, orangtua mengeluarkan biaya seragam dan uang saku termasuk ke dalam Kuadran D.

Faktor-faktor yang Mempengarui Kepuasan Orangtua Terhadap Pelayanan Pendidikan Dasar

Variabel pada Tabel 1 menjelaskan sebesar 20,3\% kepuasan orangtua (indikator CSI) terhadap pelayanan pendidikan dasar. Jumlah anggota keluarga berpengaruh nyata terhadap nilai CSI. Semakin kecil jumlah anggota keluarga, maka orangtua berpeluang 0,802 kali lebih puas dibandingkan dengan orangtua yang jumlah keluarganya semakin besar. Hasil penelitian Mason dan Himes diacu dalam Warland et al. (1972) menunjukkan bahwa pelanggan yang merasa tidak puas terhadap pembelian peralatan adalah keluarga yang jumlah anggotanya banyak (larger households).

Semakin tua umur ayah, maka orangtua berpeluang 1,050 kali lebih puas dibandingkan dengan umur ayah yang lebih muda (Tabel 1). Ayah yang usianya lebih muda memiliki ekspektasi yang lebih tinggi terhadap kinerja produk dibandingkan ayah yang usianya tua. Selain itu, umur yang lebih muda lebih berpikir kritis terhadap suatu hal (Barksdale \& Darden dalam Warland et al. 1972). Kondisi fasilitas sekolah berpengaruh terhadap kepuasan orangtua. Semakin baik kondisi fasilitas fisiknya maka orangtua berpeluang lebih puas 1,062 kali dibandingkan dengan semakin buruknya fasilitas fisik sekolah.

Pendidikan ayah tidak berpengaruh secara nyata terhadap kepuasan orangtua, namun terdapat kecenderungan yaitu semakin tinggi pendidikan ayah maka orangtua akan semakin tidak puas. Pendapatan tidak berpengaruh nyata terhadap kepuasan orangtua. Namun ada kecenderungan dimana orangtua semakin tinggi pendapatannya maka akan semakin puas. Hal ini sesuai dengan penelitian Pattinasary (2008) berkaitan dengan kepuasan masyarakat terhadap pelayanan pendidikan dan kesehatan, yaitu responden yang lebih kaya akan merasa lebih puas terhadap pelayanan pendidikan. Pengadaan dana BOS dan BOS buku oleh pemerintah bertujuan untuk mengurangi beban keluarga, namun pada kenyataannya belum sepenuhnya tercapai, karena pada dasarnya beban terbesar adalah biaya uang saku dan transport yaitu sebesar $62,75 \%$ dari total pengeluaran pendidikan per tahun (Puspitawati et al. 2009). Sementara itu, pengeluaran pendidikan untuk biaya sekolah (biaya uang

Tabel 1. Faktor-faktor yang berpengaruh terhadap kepuasan orangtua (CSI dan Direct reported satisfaction)

\begin{tabular}{|c|c|c|c|c|c|c|}
\hline \multirow{3}{*}{ Variabel } & \multirow{2}{*}{\multicolumn{2}{|c|}{$\begin{array}{l}\text { Model 1 } \\
\text { CSI (Y1) }\end{array}$}} & \multirow{2}{*}{\multicolumn{2}{|c|}{$\begin{array}{c}\text { Model } 2 \\
\text { Direct reported } \\
\text { satisfaction (Y2) }\end{array}$}} & \multirow{2}{*}{\multicolumn{2}{|c|}{$\begin{array}{c}\text { Model } 3 \\
\text { Direct reported } \\
\text { satisfaction (Y2) }\end{array}$}} \\
\hline & & & & & & \\
\hline & B & $\operatorname{Exp}(B)$ & B & $\operatorname{Exp}(B)$ & B & $\operatorname{Exp}(B)$ \\
\hline Konstanta & \multicolumn{2}{|c|}{$-3,112$} & \multicolumn{2}{|c|}{$-22,361$} & \multicolumn{2}{|c|}{$-19,265$} \\
\hline Lokasi tempat tinggal (X1) & $-0,004$ & 0,996 & 0,364 & 1,439 & 0,210 & 1,234 \\
\hline Jumlah anggota keluarga (X2) & $\begin{array}{c}- \\
0,220 * *\end{array}$ & 0,802 & $0,622^{*}$ & 1,863 & 0,472 & 1,603 \\
\hline Umur ayah (X3) & $0,049 *$ & 1,050 & 0,120 & 1,127 & 0,102 & 1,109 \\
\hline Lama pendidikan ayah (X4) & 0,001 & 1,001 & $0,527^{* *}$ & 1,694 & 0,446 ** & 1,552 \\
\hline Pendapatan (X5) & 0,441 & 1,554 & 0,442 & 1,555 & 0,635 & 1,887 \\
\hline \multicolumn{7}{|l|}{ Persepsi terhadap } \\
\hline $\begin{array}{l}\text { kepentingan pendidikan dasar } \\
\text { (X6) }\end{array}$ & $-0,193$ & 0,825 & $-0,023$ & 0,977 & 0,005 & 1,005 \\
\hline Kondisi sekolah (X7) & $0,060 * *$ & 1,062 & 0,001 & 1,001 & 0,008 & 1,008 \\
\hline Penilaian ayah terhadap kinerja & & & & & & \\
\hline $\begin{array}{l}\text { pelayanan pendidikan dasar } \\
\text { (X8) }\end{array}$ & - & - & $0,099 * *$ & 1,104 & - & - \\
\hline Skor CSI (Y1) & - & - & - & - & $0,171^{\star *}$ & 1,186 \\
\hline $\mathrm{R}^{2}$ & \multicolumn{2}{|c|}{20,3} & \multicolumn{2}{|c|}{44,9} & \multicolumn{2}{|c|}{44,1} \\
\hline $\begin{array}{rl}\text { Ket: }^{*} & p<0,1 \\
* * & p<0,05\end{array}$ & & & & & & \\
\hline
\end{tabular}


pangkal, iuran komite, dan biaya lainnya) hanya sebesar $7,45 \%$ dari total pengeluaran pendidikan per tahun. Dalam memprediksi tingkat kepuasan orangtua, model regresi pertama ini memiliki ketepatan sebesar $77,8 \%$.

Analisis regresi logistik kedua menunjukkan bahwa variabel pada Tabel 1 menjelaskan faktor-faktor yang mempengaruhi kepuasan subjektif orangtua atau direct reported satisfaction (Y2) sebesar $44,9 \%$. Sama halnya dengan analisis regresi pertama, jumlah anggota keluarga berpengaruh nyata terhadap tingkat kepuasan orangtua. Selain itu, lama pendidikan ayah juga berpengaruh nyata terhadap kepuasan orangtua, semakin tinggi pendidikan ayah maka orangtua berpeluang 1,694 kali lebih puas dibandingkan semakin rendahnya pendidikan ayah. Loudon dan Bitte (2002) menyatakan bahwa semakin tinggi pendidikan konsumen, maka konsumen akan cenderung lebih memperhatikan dan peduli terhadap kualitas, pengemasan, dan iklan produk yang akan dibelinya. Ayah yang berpendidikan tinggi akan berpikir lebih teliti sebelum memutuskan sekolah yang akan dipilih untuk anaknya.

Kinerja pelayanan pendidikan yang dinilai oleh responden ayah merupakan faktor yang berpengaruh nyata terhadap kepuasan orangtua. Semakin baik ayah menilai kinerja pelayanan pendidikan di sekolah, maka orangtua berpeluang 1,104 kali lebih puas. Analisis regresi kedua memiliki ketepatan dalam mempredisikan tingkat kepuasan orangtua sebesar $96 \%$.

Pada analisis model ketiga, variabel pada Tabel 1 mempengaruhi direct reported satisfaction (Y2) sebesar $44,1 \%$ dan memiliki ketepatan sebesar $96 \%$ dalam memprediksi tingkat kepuasan orangtua. Variabel yang berpeluang berpengaruh terhadap kepuasan orangtua adalah lama pendidikan ayah dan skor CSI. Semakin tinggi pendidikan ayah, maka orangtua akan lebih puas 1,552 kali dibandingkan dengan semakin rendahnya pendidikan ayah. Skor CSI berpengaruh nyata terhadap kepuasan yang dilaporkan langsung. Semakin meningkatnya skor CSI, maka orangtua berpeluang 1,186 kali lebih puas secara subjektif dibandingkan dengan skor CSI yang semakin menurun. Jadi, orangtua yang merasa puas (melalui penilaian subjektif) akan menilai tinggi terhadap kepentingan dan kinerja pelayanan pendidikan di sekolah anaknya.

\section{KESIMPULAN DAN SARAN}

\section{Kesimpulan}

Tingkat kepuasan yang dilaporkan langsung (direct reported satisfaction) menunjukkan bahwa baik responden di SD maupun di SMP memiliki tingkat kepuasan cukup puas dan puas terhadap sembilan atribut pelayanan pendidikan dasar. Baik ayah dan ibu di SD dan SMP, serta kota dan luar kota termasuk ke dalam kategori puas, namun ayah dan ibu yang lebih banyak merasa puas terhadap pelayanan pendidikan berada pada kelompok contoh SMP dan kota.

Skor CSI terhadap pelayanan pendidikan dasar sebesar 0,709, artinya responden merasa puas terhadap pelayanan pendidikan dasar yang disediakan sekolah. Berdasarkan tingkat pendidikan contoh, baik ayah dan ibu di SD dan SMP, serta kota dan luar kota termasuk ke dalam kategori puas. Namun, responden yang lebih banyak merasa puas berada pada tingkat SD dan kota.

Berdasarkan IPA, atribut yang termasuk ke dalam Kuadran A (perlu diperbaiki) di tingkat SD dan SMP serta kota dan luar kota adalah sekolah memiliki toilet untuk siswa, meja dan bangku sekolah yang baik, perpustakaan yang memadai, dan kontribusi dana BOS serta BOS buku terhadap total biaya pendidikan. Atribut lain yang termasuk ke dalam Kuadran A adalah pemeliharaan bangunan dan halaman sekolah (SMP dan luar kota), orangtua selalu diinformasikan mengenai perkembangan anak (SD) dan orangtua mengeluarkan biaya seragam putih biru (SMP).

Faktor-faktor yang mempengaruhi tingkat kepuasan (indikator CSI) orangtua adalah jumlah anggota keluarga, umur ayah dan kondisi sekolah. Sementara itu faktor yang berpengaruh nyata terhadap tingkat kepuasan (direct reported satisfaction) adalah lama pendidikan ayah, penilaian ayah terhadap kinerja pelayanan pendidikan dasar dan skor CSI.

\section{Saran}

Berdasarkan hasil penelitian, untuk meningkatkan kepuasan orangtua terhadap pelayanan pendidikan dasar maka diperlukan:

1. Perbaikan manajemen sekolah dalam hal pengaturan ruangan yang tidak bersifat monoton, adanya rotasi dan perubahan, sesuai dengan Pilar 
Pendidikan ke-2, transparansi keuangan sekolah dan daftar siswa penerima beasiswa (Pilar ke-3), perlengkapan manajemen data sekolah (data siswa terpilah jenis kelamin, data guru terpilah jenis kelamin, dan data komite sekolah), pengembangan kapasitas dewan pendidikan dan komite sekolah sesuai dengan Pilar ke-3, oleh karena perempuan perlu dilibatkan untuk menjadi anggota komite sekolah, walaupun kuotanya belum dapat mencapai $40 \%$, dan pertemuan rutin antara orangtua dan pihak sekolah dalam rangka memberikan informasi kepada orangtua mengenai perkembangan anaknya (khusus di SD).

2. Perbaikan fasilitas sekolah seperti bangku, kursi, kamar ganti untuk siswa, toilet siswa, dan perpustakaan. Hal ini sesuai dengan Pilar Pendidikan ke-1 dan Pilar ke-2 mengenai pengembangan sekolah sehat.

3. Pemberian dana BOS dan BOS buku (Pilar ke-1) sebaiknya disesuaikan dengan karakteristik keluarga, seperti siswa keluarga yang jumlah anggota besar dan kondisi ekonominya sulit mendapatkan bagian lebih besar dan peninjauan ulang terhadap pengadaan seragam sekolah tambahan seperti batik dan muslim.

4. Pemasaran sosial untuk meningkatkan kesadaran kepada orangtua bahwa mereka memiliki tanggung jawab dalam mengeluarkan biaya pribadi untuk sekolah anaknya, seperti uang saku dan peralatan sekolah.

5. Evaluasi terhadap metode pengukuran kepuasan yang digunakan menunjukkan hasil seperti yang tersaji pada Tabel 2. Berdasarkan Tabel 2, maka peneliti menyarankan untuk penelitian selanjutnya menggunakan metode derived satisfaction. Sementara itu, responden yang dipilih adalah ayah, karena penilaian ayah terhadap kinerja pelayanan yang diberikan sekolah lebih objektif dibandingkan penilaian ibu.

6. Menggunakan cut-off point CSI baru yang telah disesuakan dengan lokasi responden, yaitu untuk di luar kota untuk kategori tidak puas berada pada skor 0,00-0,44 dan 0,45 - 1,00 untuk kategori puas. Sementara itu, cut-off point indeks kepuasan konsumen di kota untuk kategori tidak puas berada pada skor $0,00-0,43$ dan $0,44-0,10$ untuk kategori puas.

Tabel 2. Evaluasi metode pengukuran kepuasan

\begin{tabular}{|c|c|c|}
\hline Metode & Kelebihan & Kekurangan \\
\hline $\begin{array}{l}\text { Direct } \\
\text { reported } \\
\text { satisfaction }\end{array}$ & $\begin{array}{l}\text { - } \text { Menghemat } \\
\text { waktu } \\
\text { Mengetahui } \\
\text { secara langsung } \\
\text { tingkat kepuasan, } \\
\text { tanpa perlu } \\
\text { melakukan } \\
\text { olahan lanjut }\end{array}$ & $\begin{array}{ll}\text { - Sangat } \\
\text { dipengaruhi } \\
\text { oleh persepsi, } \\
\text { emosi, dan } \\
\text { nilai seseorang } \\
\text { - } \quad \text { Hanya } \\
\text { mengukur } \\
\text { kepuasan } \\
\text { secara } \\
\text { keseluruhan }\end{array}$ \\
\hline $\begin{array}{l}\text { Derived } \\
\text { satisfaction }\end{array}$ & $\begin{array}{l}\text { - Lebih detail, } \\
\text { peneliti tidak } \\
\text { hanya dapat } \\
\text { mengukur tingkat } \\
\text { kepuasan } \\
\text { Peneliti } \\
\text { mengetahui } \\
\text { atribut apa saja } \\
\text { yang dinilai sudah } \\
\text { puas dan yang } \\
\text { perlu diperbaiki } \\
\text { ataupun } \\
\text { dihilangkan } \\
\end{array}$ & $\begin{array}{l}\text { Memakan } \\
\text { waktu lebih } \\
\text { banyak, karena } \\
\text { responden } \\
\text { harus menilai } \\
\text { kinerja setiap } \\
\text { atribut }\end{array}$ \\
\hline
\end{tabular}

\section{DAFTAR PUSTAKA}

Ana G. 2008. Analisis Tingkat Kepuasan dan Loyalitas Konsumen Jamu gendong di Kota Sukabumi [skripsi]. Fakultas Pertanian Institut Pertanian Bogor.

Anonim. 2003. Tingkat Kepuasan Masyarakat Terhadap Pelayanan Instansi Pemerintah: Studi Pelayanan Kesehatan dan Pelayanan Pendidikan. http//www.bpkp.go.id. [08 Maret 2009].

Anonim. 2005. Peraturan Pemerintah Nomor 19 Tahun 2005 tentang Standar Nasional Pendidikan-2005. www.depdiknas.go.id. [16 April 2009].

Anzola Y. 2008. Analisis Tingkat Kepuasan Konsumen terhadap Tanggapan Perusahaan Pasca Tindakan Komplain Melalui Media Massa Kompas [skripsi] Fakultas Pertanian Institut Pertanian Bogor.

Ebtariani NM. 2007. Faktor-faktor yang Mempengaruhi Loyalitas merek Terhadap Produk Susu untuk Anak usia 2 - 5 Tahun. [skripsi] Bogor. Fakultas Pertanian. Institut Pertanian Bogor.

Erfiana, D. 2004. Tingkat Kepuasan Konsumen Restoran di Jakarta dan Hubungannya dengan Keinginan Berkunjung Kembali. [skripsi] Bogor. 
Fakultas Pertanian. Institut Pertanian Bogor.

Flowers et al. 2008. African American Students' Satisfaction with Distance Education Course. www.sage-journal .com. Diakses pada tanggal 08 Maret 2009.

Hurlock, EB. 1980.Psikologi Perkembangan: Suatu pendekatan Sepanjang rentang Kehidupan. Jakarta: Erlangga.

Lovelock, C. dan Wright, L. 2002. Principles of Service Marketing and Management. New Jersey: Pearson education, Inc.

Mowen, JC dan Minor, M. 1998. Consumer Behavior Fifth Edition. New Jersey: Prentice-Hall

Pattinasarany, D. 2008. Governance and Decentralization Survey (GDS). Workshop for Concept Development of Delivery Improvement and Local Governance (DIALOG) Program. Bogor, 06 Februari 2008.

*Korespondensi :

Email : atika.zae@gmail.com
Puspitawati et al. 2009. Parent satisfaction Survey of Basic Education Sericws Provided by The Decentralised School System. [Laporan Penelitian]. LPPMIPB dan BAPPENAS-PRMAP.

Sumarwan, U. 2003. Perilaku Konsumen: Teori dan Penerapannya dalam Pemasaran. Jakarta: Ghalia Indonesia.

Troelstrup, AW. 1957. Consumer Problems and Personal Finance. Newyork: McGraw-Hill Book Company, Inc

Walker, O.C., Harper W.B. dan JeanCleaudeL. 1992. Marketing Strategy: Planning and Implementation. Boston: Richard D. Irwing.

Warland et al. 1972. Dissatisfied Consumers: Who gets Upset and Who Takes Action. The Journal of Consumers Affairs: 149163. 